\title{
MARKETING COMMUNICATION WITH STAKEHOLDERS AT THE MINICIPAL OFFICES IN THE KUYAVIAN-POMERANIAN VOIVODESHIP
}

\author{
Krzysztof ANDRUSZKIEWICZ ${ }^{1}$, Maciej SCHULZ ${ }^{2 *}$ \\ ${ }^{1}$ Jan and Jędrzej Śniadecki University of Technology and Life Sciences in Bydgoszcz, Faculty of Management; \\ k.andruszkiewicz@utp.edu.pl, ORCID: 0000-0002-3919-731X \\ ${ }^{2}$ Jan and Jędrzej Śniadecki University of Technology and Life Sciences in Bydgoszcz, Faculty of Management; \\ m.schulz@utp.edu.pl, ORCID: 0000-0002-4324-9266 \\ * Correspondence author
}

Purpose: The main goal of this study is to present the essence and the importance of marketing communication in the functioning of local governments.

Design/methodology/approach: The study incorporates the results of a study on various aspects related to marketing management in the municipalities of the Kuyavian-Pomeranian Voivodeship. As part of the study, specific marketing communication activities that were used by local governments in the Kuyavian-Pomeranian Voivodeship over the past 5 years have been identified. The subject of the assessment were consisted in those marketing communication methods that are used by local governments, due to the specificity of the activities carried out by municipalities.

Findings: The results of the study indicate that many local governments representing large urban or urban-rural municipalities underestimate the importance of the activities that can be undertaken in this regard. Vast majority of the local governments covered by the study only use individual marketing communication tools, limiting themselves to advertising, public relations or personal promotion activities.

Practical implications: The results of the study allowed identification of a different solutions, which are characteristic for municipalities in the Kuyavian-Pomeranian Voivodeship, that can be used by other local governments in Poland.

Social implications: The paper indicates on many useful solutions, that are related to the training of the officials in the methods and tools used for creation of proper relations with the stakeholders.

Originality/value: This paper presents selected results of the study on various aspects associated with marketing management in the municipalities of the Kuyavian-Pomeranian Voivodeship. One of the research objectives was to identify and evaluate the marketing communication activities that have been undertaken by the municipal offices in the KuyavianPomeranian Voivodship over the past 5 years.

Keywords: marketing communication, municipality, local government. 


\section{Introduction}

One of the primary tasks that local authority representatives fulfill entails all communication (including marketing communication) with the stakeholders in the region, which should fully meet the expectations of the communities they administrate. Local governments undertake a numerous various activities in this area. Their main objective entails provision of information on the activities undertaken by local governments and proper PR management of the image of individual municipalities. From the perspective of the specifics of the functioning of the local governments competing with other local governments, image-building goals, which constitute the intangible assets determining the perception and assessment of a given municipality, seem particularly important. In this sense, it is an important criterion for assessing how a given municipality is managed, which affects the distinguishment of municipalities, the building of competitive advantage, and clearly facilitates mutual understanding. Effectively implemented communication-related activity provides opportunities to create a favorable attitude on the part of the local communities towards the local authorities and their actions, which probably often affects, among others, the result of the local elections. It is therefore impossible to underestimate the importance of communication (including marketing communication) in the functioning of local governments, especially since the basic aim of the promotional activity of local governments is to create a favorable, i.e. a positive, image about local authorities.

The main purpose of the article is to present the scope, the forms and the means as well as the importance of marketing communication in the functioning of the local governments in the Kuyavian-Pomeranian region. Particular emphasis has been placed on the tools of modern marketing communication, which are also used by Polish local government officials to achieve promotional goals.

The study incorporates the results of a broader study on the aspects of the public office functioning that are related to marketing management in the municipalities of the KuyavianPomeranian Voivodeship. The research was carried via the postal survey method (the survey covered all municipalities in the region) and additionally, in 2018, a supplementary survey was carried out in selected municipalities, using the direct interview method. One of the objectives of the aforementioned study of a broader scope entailed, inter alia, identification and assessment of the activities undertaken by local governments of the Kuyavian-Pomeranian Voivodeship in the field of the broadly-understood marketing communication in the region. 


\section{The essence and importance of communication in local government}

Communication constitutes an important, integral instrument of the overall strategy (including the marketing strategy) and an expression of the practical implementation of each organization's market goals of each organization (Dobek-Ostrowska, 1999, p. 13). The communication process taking place in an organization also applies to local governments. It boils down to establishing contact with the recipients (stakeholders), which is manifested through communication, transfer of information, skills, concepts, etc. Modernly understood communication is the dialogue of local governments with the environment, which should contribute to establishment and maintenance of partner relations with all stakeholders (Cf.: Smalec, 2011, pp. 490-495).

The classic process of communication is shown on Figure 1.

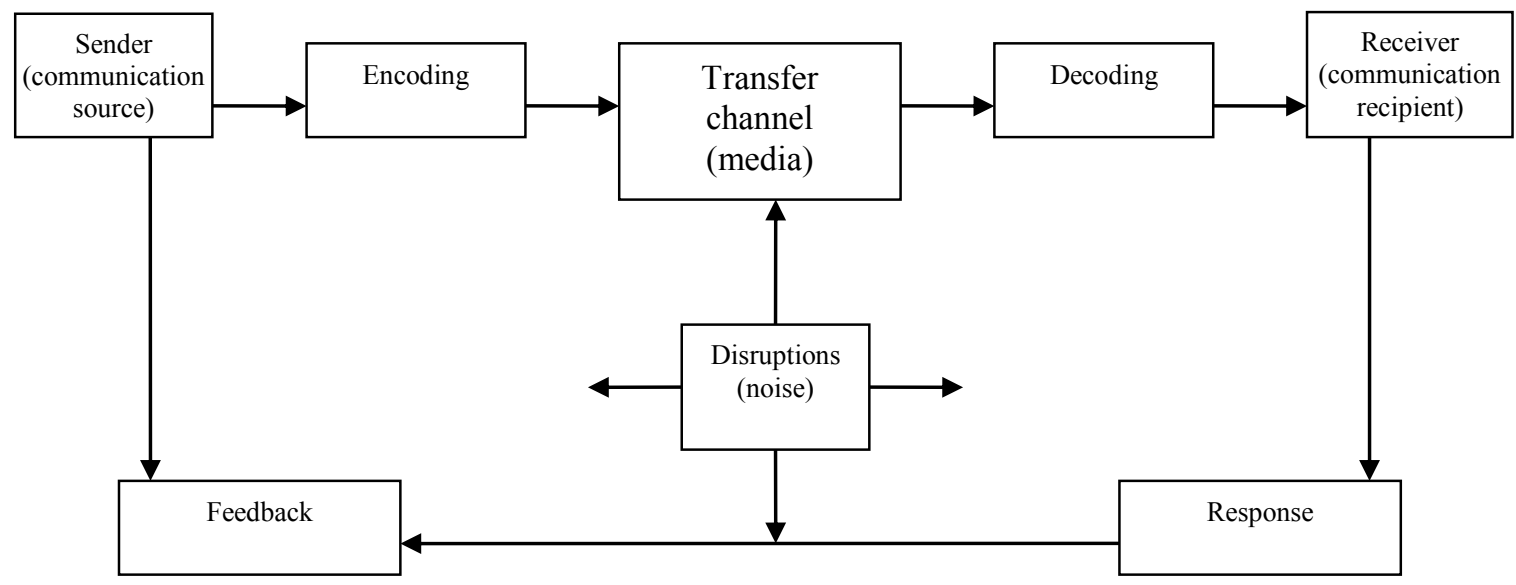

Figure 1. Elements of the communication process. Source: own elaboration based on $\mathrm{Ph}$. Kotler, Marketing. Analiza, planowanie, wdrażanie, kontrola [Marketing management : analysis, planning, implementation, and control] $]^{l}$, Warsaw 1994, p. 547.

Two parties always take part in the communication process: the sender and the receiver of the message. In this case, the sender is the local government, which should be fully aware of its goals and of the expectations on the part of individual receiver groups. Depending on the nature of the communication activities taking place in the region, the recipients can be the so-called stakeholders, who include all residents, specific social groups, the entrepreneurs operating in the given municipality (region), tourists and other supraregional organizations. The sender develops the communication concepts intended to help implement the current municipal operation and development arrangements. This primarily includes establishment of communication goals, definition of the target groups of targeted promotional activities, the forms and the media, the budget and the implementation principles. Establishment of the communication goals municipal offices are to achieve is very important because: the goals set

\footnotetext{
${ }^{1}$ For the purpose of linguistic clarity, all Polish titles of the publications used as sources have been translated, with the title translations given in parentheses. Polish editions of original English publications are provided with the original English titles in square brackets.
} 
become a 'signpost' enabling selection, from among various alternative activities, of those that will allow achievement of the goals, in an efficient and effective manner, and will additionally enable control, when the task is completed and the goals achieved (Crane, 1965). The goals chosen most frequently include (Florek, 2007; Czornik, 2005):

- general information about municipality (location, natural conditions, residents, economic activity);

- promotion of the municipality and persuasion of its advantages, presentation of the benefits contained in the local offer;

- encouragement to purchase or consume municipality's megaproducts (subproducts);

- construction of municipality's image, or its change, and thus positioning the municipality on the map of the region and the country;

- impact on regional and state authorities, on other important organizations;

- change in social behavior;

- combating the negative information and gossip about the municipality;

- development of stakeholder behaviors that are desired by the municipality;

- establishment of credibility and increasing trust in municipal authorities;

- motivating the employees of municipal offices to provide proper customer service.

Another important issue associated with implementation of municipality's strategy (the marketing communication strategy) entails selection of the addressees of the activities being developed. All addressees, whom the activities and the communication tools may be oriented at, can be divided into internal and external recipients, in terms of their permanent residence relative to the commune, as well as individual and institutional recipients (Florek, 2007).

Table 1.

Examples of the addressees of the activities promoting the municipality

\begin{tabular}{|c|c|c|}
\hline Addressees & Internal & External \\
\hline Individual & $\begin{array}{l}\text { - inhabitants } \\
\text { - residents }\end{array}$ & $\begin{array}{l}\text { - tourists (domestic and foreign ones) } \\
\text { - transient tourists and potential inhabitants }\end{array}$ \\
\hline Institutional & $\begin{array}{l}\text { - local authorities } \\
\text { - local entrepreneurs } \\
\text { - local organizations and institutions, the local } \\
\text { lobby }\end{array}$ & $\begin{array}{l}\text { - potential investors (domestic, foreign) } \\
\text { - central/state authorities } \\
\text { - national and foreign institutions } \\
\text { - rival regions }\end{array}$ \\
\hline
\end{tabular}

Source: own elaboration.

The importance of all communication (including marketing communication) for local government units results, among others, from (Smalec, 2011, p. 492):

- the desire to get a sense of identity,

- establishment of ties and partnerships with other entities in the environment,

- the desire to satisfy one's own needs,

- the need to belong (gives a sense of participation in the life of some social group),

- the need to influence and control the social environment. 
Representatives of local authorities undertake a wide variety of marketing communication activities. Effectiveness of these activities mainly depends on a thought-out and coherent communication strategy, resulting from the overall strategic goals set out by the regional authorities.

For local authorities, marketing communication is necessary to build good relations with the broadly-understood stakeholders and to establish contacts with all recipient groups, through thought-out strategic concepts. The goals planned can be achieved through the use of modern and traditional communication methods and techniques. Local government officials can benefit from personal and indirect promotion as well as from advertising.

In marketing communication, both personal and mass communication, all available sensory and media channels are used, in any configuration and proportions. The media used, despite significant differences, are mutually inclusive and penetrate each other, which is a phenomenon often found in marketing communication processes. Such combined use of media creates greater probability that the communication process will be effective and the goals set for this process will be implemented efficiently (Wiktor, 2001).

Every communication, especially marketing communication, as confirmed by research, is the most effective and efficient, if the message is properly understood and remembered by the recipients. To a large extent everything depends on the selection of appropriate forms, means and tools of promotion, which should be tailored to the specificity of individual recipient (stakeholder) groups. Meanwhile, as observed in many municipal offices, communication is limited to traditional one-way messages, transmitting information in the form of leaflets, information catalogues or announcements on internal boards. Such forms and means do not offer the best dialogue for creation of partner relations in the region. Only free, mutual and open exchange of views, opinions, experiences and ideas ensures high efficiency of the communication between local governments and the region (C.f.: Smalec, 2011, p. 493).

\section{Marketing communication with stakeholders in municipal offices of the Kuyavian-Pomeranian Voivodship - survey results}

This paper presents selected results of the study on various aspects associated with marketing management in the municipalities of the Kuyavian-Pomeranian Voivodeship. The survey study was carried out by employees of the Department of Marketing and Regional Development, at the Faculty of Management of the University of Technology and Life Sciences in Bydgoszcz, in the last quarter of 2015. The method of data collection from primary sources was a postal survey. Questionnaires with a cover letter were sent to all 157 municipal offices in the Kuyavian-Pomeranian Voivodeship. The study was exhaustive, which means that it covered the entire research population. Completed questionnaires were returned by 94 offices, which 
translates to almost $60 \%$ of the surveyed population. Three Elderships ${ }^{2}, 20$ urban municipalities, 23 urban-rural municipalities, and 48 rural municipalities took part in the study. The structure of individual municipalities, relative to the type and the number of the officials employed, was used to perform in-depth analyzes of individual elements of the marketing management implemented in these municipalities (Andruszkiewicz, Schulz, 2016). The survey constituted a basis for preparation of a qualitative study that is based on the Delphi method. The results of in-depth research on the use of the broadly-understood marketing management by local governments in the Kuyavian-Pomeranian Voivodeship will be the subject of the research team's subsequent publications.

One of the research objectives was to identify and evaluate the marketing communication activities that have been undertaken by the municipal offices in the Kuyavian-Pomeranian Voivodship over the past 5 years. The scope and the frequency of the actions taken in this area are closely related to the state of knowledge and the marketing awareness of the officials, which has been reflected in the attitudes towards specific actions in this field. The results of the survey clearly show that pro-marketing attitudes are characteristic mainly for the representatives of urban municipalities, where the percentage of pro-marketing attitudes was almost $70 \%$, and in urban-rural municipalities (37\% of municipalities). In typically-rural municipalities, marketing attitudes are much less common, since the percentage of such municipalities does not exceed $15 \%$. The survey results also indicates a growing frequency of pro-marketing attitudes, along with an increase in the number of employees. In municipalities employing more than 38 employees, the percentage of pro-marketing attitudes was almost 85\% (Andruszkiewicz, Schulz, 2016).

The survey results show that vast majority of the municipalities surveyed relatively rarely incorporate marketing communication activities. This tendency is reflected in the overall assessment of the state of local government officials' marketing awareness in the KuyavianPomeranian Voivodeship and the manner in which marketing activities are organized in individual municipalities. Almost half of the municipalities covered by the survey do not have marketing separate cells within their structures, not even in the form of one-person positions. Although this primarily applies to rural municipalities, where the number of employees does not exceed 30 people, there are large urban municipalities as well, where the situation is similar. (Andruszkiewicz, Schulz, 2016, pp. 7-17).

As part of the study, specific marketing communication activities that have been used by local governments in the Kuyavian-Pomeranian Voivodeship over the past 5 years have been identified. The subject of the assessment entailed only those marketing communication methods that are used by the local governments in connection with the specificity of their activities. Complementary promotion tools, which by definition are used by entrepreneurs to increase

\footnotetext{
${ }^{2}$ Original Polish name is Starostwo - an administrative unit established in Poland in the 14th century, which may comprise a very small region consisting of few villages, one single town, or a part of a big city.
} 
attractiveness of the products offered, were excluded from the study. Such tools, however, cannot be applied with regard to local governments. All other methods of promotion, i.e. advertising, direct and indirect promotion, have been analyzed and evaluated.

Advertising was the first group of activities related to the use of marketing communication by local governments. In the Kuyavian-Pomeranian Voivodeship, $26.6 \%$ of all municipalities covered by the survey have used advertising in the last 5 years. Vast majority of the municipalities incorporating advertising in their activity are large municipalities, employing over 30 employees. The share of those municipalities was $94.7 \%$. The low level of advertising usage in small municipalities employing up to 30 employees is closely correlated with the scale of expenditures on promotion. Officials in the small municipalities included in the survey declare that the budget for promotion does not exceed $0.1 \%$ of all expenditures in a given municipality. The amount of promotion-related expenditures in such municipalities does not exceed PLN 100000.

The study carried out was focused on the most popular advertising measures that can be implemented by local governments. With regard to the municipalities that are part of the Kuyavian-Pomeranian Voivodeship, press advertising as well as advertisements in offices and subordinate units are most commonly used measures. Municipal officials' declarations show that $23.4 \%$ of the municipalities in the Kuyavian-Pomeranian Voivodeship use such advertising measures. Online advertising, which is used by $22.3 \%$ of local governments, is another most common measure. Other means of advertising, such as outdoor advertising (12.8\%), radio advertising $(16.0 \%)$, television advertising $(12.8 \%)$ or postal advertising $(5.3 \%)$ are definitely less popular. Detailed distribution of the indications regarding the use of individual advertising measures in the municipal offices of the Kuyavian-Pomeranian Voivodship is presented in Table 2.

Table 2.

Advertising measures used in the municipalities of the Kuyavian-Pomeranian Voivodeship in the last 5 years

\begin{tabular}{|l|c|c|c|}
\hline \multicolumn{1}{|c|}{ Advertising measures } & YES & NO & NO OPINION \\
\hline Press advertising & $23.4 \%$ & $75.5 \%$ & $1.1 \%$ \\
\hline Online advertising & $22.3 \%$ & $76.6 \%$ & $1.1 \%$ \\
\hline Postal advertising & $5.3 \%$ & $92.6 \%$ & $2.1 \%$ \\
\hline Outdoor advertising & $12.8 \%$ & $86.1 \%$ & $1.1 \%$ \\
\hline TV advertising & $12.8 \%$ & $86.1 \%$ & $1.1 \%$ \\
\hline Radio advertising & $16.0 \%$ & $84.0 \%$ & $0 \%$ \\
\hline Advertisements in offices and subordinate units & $23.4 \%$ & $75.5 \%$ & $1.1 \%$ \\
\hline Other advertising measures & $5.3 \%$ & $94.7 \%$ & $0 \%$ \\
\hline
\end{tabular}

Source: own elaboration based on the research results.

Among the municipalities that use advertising in their activity, occurrence of evident disproportions in the use of individual means of advertising, can be observed, with regard to the type of municipality. The results of this study indicate that postal advertising, advertising in offices and subordinate units, and press advertising dominate in rural municipalities. Outdoor 
advertising, for example, is much less frequently used in these municipalities, while in urbanrural municipalities this type of advertising is most common. $50 \%$ of urban-rural municipality representatives declare that they are using outdoor advertising. In addition to outdoor advertising, these municipalities relatively frequently incorporate internet advertising, radio advertising and postal advertising. TV and press advertising as well as advertising in offices and other subordinate units is much less frequently used. The failure to use postal advertising as well as the low frequency of internet advertising, i.e. at the level of $9.5 \%$ of the municipalities surveyed, is a characteristic feature of typically-urban municipalities. In urban municipalities, TV advertising (25\% of municipalities), press advertising (18.2\% of municipalities) and advertising in offices and other subordinate units (18.2\% of municipalities) are most commonly used. With regard to Elderships, utilization of most of the advertising measures analyzed is at a similar level, which ranges from $18.2 \%$ to $25 \%$. Only advertising in offices and other subordinate units is implemented by a mere $13.6 \%$ of the municipalities covered by the survey. Detailed distribution of the indications regarding the use of individual advertising measures in the last 5 years, taking into account individual types of municipalities, is presented in Table 3 .

Table 3.

Advertising measures used in the municipalities of the Kuyavian-Pomeranian Voivodeship in the last 5 years, taking into account the type of municipality

\begin{tabular}{|c|c|c|c|c|}
\hline \multirow[b]{2}{*}{ Advertising measures } & \multicolumn{4}{|c|}{ Type of municipality } \\
\hline & urban & urban-rural & rural & Eldership \\
\hline Press advertising & $18.2 \%$ & $31.8 \%$ & $31.8 \%$ & $18.2 \%$ \\
\hline Online advertising & $9.5 \%$ & $42.9 \%$ & $28.6 \%$ & $19.0 \%$ \\
\hline Postal advertising & $0.0 \%$ & $40.0 \%$ & $40.0 \%$ & $20.0 \%$ \\
\hline Outdoor advertising & $16.7 \%$ & $50.0 \%$ & $8.3 \%$ & $25.0 \%$ \\
\hline TV advertising & $25.0 \%$ & $25.0 \%$ & $25.0 \%$ & $25.0 \%$ \\
\hline Radio advertising & $13.3 \%$ & $40.0 \%$ & $26.7 \%$ & $20.0 \%$ \\
\hline Advertisements in offices and subordinate units & $18.2 \%$ & $31.8 \%$ & $36.4 \%$ & $13.6 \%$ \\
\hline
\end{tabular}

Source: own elaboration based on the research results.

The second group of activities constituting the marketing communication of local governments covered by the study were activities associated with indirect promotion, such as:

- preparation of press releases, organization of press conferences;

- municipality's involvement in fairs, exhibitions, festivals;

- sponsorship and charity activity;

- organization of special events for residents;

- the use of municipality-identification measures (the municipality logo, the municipality crest, flag, letterhead, business cards, the clerical clothing etc.);

- organization of events and work retreats for municipal officials;

- informing residents and employers about the current economic and social situation in the municipality. 
The survey respondents also had the opportunity to indicate other activities that they incorporate in their public relations activity. Municipality representatives pointed to the following activities in this regard:

- uploading videos to YouTube,

- publishing free newspapers (information catalogues),

- organization of competitions promoting the municipality,

- organization of public consultations on the matters relevant to local communities.

Detailed survey results regarding public relations activity are presented in Table 4.

\section{Table 4.}

The public relations activities implemented in the municipalities of the Kuyavian-Pomeranian Voivodeship in the past 5 years

\begin{tabular}{|c|l|c|c|c|}
\hline No. & \multicolumn{1}{|c|}{ Public relations activities implemented by municipalities } & YES & NO & $\begin{array}{c}\text { NO } \\
\text { OPINION }\end{array}$ \\
\hline 1. & preparation of press releases, organization of press conferences & $31.9 \%$ & $65.2 \%$ & $2.9 \%$ \\
\hline 2. & municipality's involvement in fairs, exhibitions, festivals & $36.2 \%$ & $63.8 \%$ & $0 \%$ \\
\hline 3. & sponsorship and charity activity & $15.9 \%$ & $78.3 \%$ & $5.8 \%$ \\
\hline 4. & organization of special events for residents & $40.6 \%$ & $59.4 \%$ & $0 \%$ \\
\hline 5. & $\begin{array}{l}\text { use of municipality identification measures } \\
\text { (the municipality logo, municipality crest, flag, letrhead, }\end{array}$ & $40.6 \%$ & $59.4 \%$ & $0 \%$ \\
\hline 6. & organization of events and work retreats for municipal officials & $31.9 \%$ & $68.1 \%$ & $0 \%$ \\
\hline 7. & $\begin{array}{l}\text { informing residents and employers about the current economic } \\
\text { and social situation in the municipality }\end{array}$ & $34.8 \%$ & $63.3 \%$ & $2.9 \%$ \\
\hline 8. & other activity & $5.8 \%$ & $94.2 \%$ & $0 \%$ \\
\hline
\end{tabular}

Source: Schulz, Andruszkiewicz, 2016, p. 463.

Out of the activities mentioned above, organization of special events for residents and the use of municipality identification measures was indicated most frequently $(40.6 \%$ of responses). In both cases, this type of activity was undertaken by 3 Elderships, 2 urban municipalities, 10 urban-rural municipalities, and 13 rural municipalities. These results indicate that some officials attach relatively high importance to the creation of good relations with the environment, through organization of special events. Almost the same municipalities also underline activities that are related to the municipality's participation in fairs, exhibitions, festivals (36.2\% of all indications). This type of activity, combined with the use of municipal identification measures, in most cases, is the only way to implement public relations activity. Only $25.6 \%$ of municipalities complement these activities with other forms of public relations activities, primarily including informing the residents and employers about the current economic and social situation in the municipality. In total, such activities were undertaken by $34.8 \%$ of the municipalities covered by the survey. The tendency described is particularly visible in rural municipalities (46.4\% of all indications) and urban-rural municipalities (35.7\% of all indications). In typically-urban municipalities, this ratio drops to $7.1 \%$ (Schulz, Andruszkiewicz, 2016, p. 464). 
The results of the study allowed identification of a different tendency, which is characteristic for large municipalities employing over 30 officials. In such municipalities, media relations tools are used relatively often, by a total of $31.9 \%$ of all large municipalities covered by the survey. These municipalities constitute $86.4 \%$ of all municipalities implementing this type of activities (Schulz, Andruszkiewicz, 2016, p. 465).

The last group of activities constituting the marketing communication of the local governments included in the study, concerned personal promotion. With regard to the municipal offices in the Kuyavian-Pomeranian Voivodeship, three types of marketing activities have been undertaken in this area. The first group entails activities that are related to the training of the officials in the methods and tools used for creation of proper relations with the stakeholders. These types of activities have been undertaken by a mere $21.3 \%$ of all Kuyavian-Pomeranian municipalities that took part in the survey. $73.4 \%$ of the municipalities in this group do not undertake such activities, while in $5.3 \%$ of the municipalities, local governments did not have knowledge in this area. The second group of activities concerned implementation of a coherent and transparent stakeholder-service system. $18.1 \%$ of the municipalities declared such activities, $77.6 \%$ of the municipalities do have such a system, while $4.3 \%$ of the KuyavianPomeranian municipality representatives did not have knowledge on these issues. The last group of personal-promotion activities entails the use of the databases functioning in individual municipal offices for building contacts with stakeholders. $19.1 \%$ of the representatives of the Kuyavian-Pomeranian municipalities declare that they conduct such activities, $78.8 \%$ do not undertake such activities, and $2.1 \%$ declare lack of knowledge in this area. The personalpromotion activities used in the Kuyavian-Pomeranian municipalities in the last 5 years, taking into account the type of municipality, are presented in Table 5.

\section{Table 5.}

Personal-promotion activities implemented in the Kuyavian-Pomeranian municipalities in the last 5 years, taking into account the type of municipality

\begin{tabular}{|c|c|c|c|c|}
\hline \multirow{2}{*}{$\begin{array}{l}\text { Marketing activities undertaken as part of } \\
\text { personal promotion }\end{array}$} & \multicolumn{4}{|c|}{ Type of municipality } \\
\hline & urban & urban-rural & rural & eldership \\
\hline $\begin{array}{l}\text { Training of the officials in the methods and tools used } \\
\text { for creation of correct relations with stakeholders }\end{array}$ & $15.0 \%$ & $35.0 \%$ & $35.0 \%$ & $15.0 \%$ \\
\hline $\begin{array}{l}\text { Implementation of a coherent and transparent } \\
\text { municipal stakeholder-service system }\end{array}$ & $5.9 \%$ & $41.2 \%$ & $41.2 \%$ & $11.8 \%$ \\
\hline $\begin{array}{l}\text { Using the databases at the municipal offices in } \\
\text { contacts with stakeholders }\end{array}$ & $0 \%$ & $38.9 \%$ & $44.4 \%$ & $16.7 \%$ \\
\hline
\end{tabular}

Source: own elaboration based on the research results.

Among the municipalities that implement personal promotion activities, clear differences in the application of these activities exist, depending on the type of municipality. In the municipalities included in the survey, databases of individual offices have not been used in contacts with stakeholders. In such municipalities, most often officials are trained in the methods and tools used for creation of proper relations with stakeholders $(15 \%$ of the municipalities covered by the survey), and measures are taken to create a coherent and transparent system of stakeholder service (5.9\%). It is worth noting that, in urban 
municipalities, compared to other types of municipalities, personal promotion activities are implemented relatively rarely. In urban-rural and typically-rural municipalities, growing interest in personal promotion activities has been observed. Far more such municipalities use databases to create proper relations with stakeholders, conduct trainings, or introduce a coherent and transparent system of stakeholder service. In elderships, the degree to which personal promotion activities have been implemented is at a much lower level. All the activities covered by the study are used very rarely. It is worth noting that $11.8 \%$ of the Elderships have been undertaking activities aimed at creation of a coherent and transparent system of stakeholder service.

\section{Summary}

Marketing communication on the part of local governments is one of the primary methods of shaping the image and informing the stakeholders about the activities undertaken by individual municipalities. The results of the study indicate that many local governments, representing large urban or urban-rural municipalities, underestimate the importance of the activity that can be undertaken in this regard. Vast majority of the local governments covered by the study only use individual marketing communication tools, limiting themselves to advertising, public relations or personal promotion activities. The study did not identify the municipalities which in a coherent and comprehensive manner tried to achieve the objectives of marketing communication, using all available methods. It is worth noting that many local governments in the Kuyavian-Pomeranian Voivodeship do not attach much importance to personal-promotion activities, which is the basic method of marketing communication for this type of institutions. Only in every fifth municipality officials conduct trainings in the use of the available methods and tools for creation of proper relations with stakeholders, or develop coherent and transparent systems of stakeholder service. Officials also occasionally use the databases functioning in the offices, to build good relations with the stakeholders. The low level of marketing communication is closely related to the overall assessment of the state of marketing awareness on the part of local government officials in the Kuyavian-Pomeranian Voivodeship and the way marketing activities are organized in individual municipalities. The results of the study indicate that many areas associated with marketing communication of local governments can be improved, which would certainly translate into better relations of individual municipalities with stakeholders. 


\section{References}

1. Andruszkiewicz, K., Schulz, M. (2016). Postawy samorządowców wobec działań marketingowych na przykładzie województwa kujawsko-pomorskiego. Studia i Prace WNEiZ US, 43/2. Szczecin: Wydawnictwo Naukowe Uniwersytetu Szczecińskiego, 7-17.

2. Crane, E. (1965). Marketing Communications: A Behavioral Approach to Men, and Media. New York: John Wiley \& Sons, 12.

3. Czornik, M. (2005). Promocja miasta. Wydawnictwo Akademii Ekonomicznej w Katowicach, 63.

4. Dobek-Ostrowska, B. (1999). Podstawy komunikowania społecznego. Wrocław: Wydawnictwo Astrum, 13.

5. Florek, M. (2007). Podstawy marketingu terytorialnego. Wydawnictwo Akademii Ekonomicznej w Poznaniu, 151.

6. Kotler, Ph. (1994). Marketing. Analiza, planowanie, wdrażanie, kontrola. Warszawa, 547.

7. Schulz, M., Andruszkiewicz, K. (2016). Public relations w urzędach gmin województwa kujawsko-pomorskiego. Marketing i Rynek, 10. Warszawa, PWE, 464.

8. Smalec, A. (2011). Rola komunikacji w rozwoju koncepcji partnerstwa w regionach. In: G. Rosa, A. Smalec (eds.), Marketing przyszłości. Trendy. Strategie. Instrumenty, Wybrane aspekty marketingu terytorialnego. Zeszyty Naukowe Uniwersytetu Szczecińskiego, 663, Ekonomiczne Problemy Ustug, 75. Szczecin, 490-495. 